\section{Fertilization of Landscape Palms to Reduce Nitrogen and Phosphate Impacts on the Environment}

\author{
Timothy K. Broschat ${ }^{1}$ \\ University of Florida, Fort Lauderdale Research and Education Center, \\ 3205 College Avenue, Davie, FL 33312
}

Additional index words. areca palm, controlled-release fertilizers, Dypsis lutescens, potassium deficiency, principal component analysis

\begin{abstract}
Palms are an increasingly important element in landscapes in the subtropical and warm temperate regions of the United States. Unfortunately, palms have very high nutritional requirements and rarely can be found without at least one nutrient deficiency, especially on the sandy and calcareous soils of the southeastern United States. These deficiencies are conspicuous and unsightly, reduce canopy size and vigor, and can become fatal. Current maintenance fertilizer recommendations for landscape palms in Florida growing in these soils entail four applications per year of an $8 \mathrm{~N}-0.9 \mathrm{P}-10 \mathrm{~K}-4 \mathrm{Mg}$ plus micronutrients palm fertilizer. However, because phosphorus $(P)$ and nitrogen $(N)$ are considered pollutants of ground and inland and coastal surface waters, it is important to apply only as much of these elements as necessary for palm health. This study showed that areca palms (Dypsis lutescens) can be grown in a native sand soil or in a calcareous fill soil without supplemental $P$ and with no $N$ applied during the rainy summer months of June through September when application of these elements may be legally restricted. It also demonstrated that the negative effects caused by high $\mathrm{N}$ :potassium $(\mathrm{K})$ ratio turf fertilizers can be mitigated by adding a controlled release palm fertilizer that contains no $\mathbf{N}$ or $\mathbf{P}$. Because of strong dilution effects in this study, leaf nutrient concentrations were found to be poor indicators of palm quality and nutritional status.
\end{abstract}

Palms are an important component of landscapes in subtropical and warm temperate climates of the United States as a result of their bold leaf texture, small footprint in the landscape, and the tropical or Mediterranean look they impart to a landscape. Although palms have some of the highest nutrient requirements of any plants, most palms in the southeastern United States are grown in sandy, nutrient-poor soils (Broschat, 2009). The result is that most landscape palms within the southeastern United States are deficient in one or more elements. These deficiencies result in chlorosis, necrosis, or malformation of leaves; reduction in canopy size (number of leaves supported by the palm); trunk tapering or bending; and even death of the entire palm (Broschat and Elliott, 2005; Elliott et al., 2004). Because palms have only one apical meristem per trunk and no aerial lateral meristems, nutrient deficiencies that might cause only a twig dieback in broadleaf trees can be fatal in palms (Broschat, 2009). Also, because palms have

Received for publication 11 Dec. 2014. Accepted for publication $15 \mathrm{Jan} .2015$.

This research was supported by the Florida Agricultural Experiment Station and by the USDA National Institute of Food and Agriculture Hatch project FLA-FTL-004945.

I thank William Latham, Susan Thor, and Andy Warren for their assistance in this project.

${ }^{1}$ To whom reprint requests should be addressed; e-mail tkbr@ufl.edu. such large leaves, deficiency symptoms are highly conspicuous and unsightly for plants that are grown primarily for aesthetic purposes. Six nutrient elements are commonly deficient in palms in the southeastern United States [N, $\mathrm{K}$, magnesium $(\mathrm{Mg})$, iron $(\mathrm{Fe})$, manganese $(\mathrm{Mn})$, and boron (B)], and a deficiency of any one of these elements will affect palm aesthetic quality and health (Broschat, 2009).

Broschat (1999) determined that fertilizers having a $\mathrm{N}: \mathrm{K}_{2} \mathrm{O}: \mathrm{Mg}$ ratio of $2: 3: 1$ are required to grow deficiency-free palms in the sandy and calcareous soils of the southeastern United States. Significant deviations from this analysis cause nutrient imbalances that can induce or exacerbate deficiencies of $\mathrm{K}$ and/or $\mathrm{Mg}$. For example, turf fertilizers with $\mathrm{N}: \mathrm{K}_{2} \mathrm{O}$ ratios of $2: 1$ or $3: 1$, which contain no $\mathrm{Mg}$ or micronutrients except for $\mathrm{Fe}$, have been shown in Florida to exacerbate $\mathrm{K}$ deficiencies and induce $\mathrm{Mg}$ deficiencies (Broschat, 2009). Similarly, too much $\mathrm{K}$ will also induce $\mathrm{Mg}$ deficiency. Currently, the recommended fertilizer for palms in these soils has an analysis of $8 \mathrm{~N}$ $0.9 \mathrm{P}-10 \mathrm{~K}-4 \mathrm{Mg}$ plus micronutrients (hereafter 8-2-12) (Broschat, 2005a).

Because sandy and calcareous fill soils in southeastern United States have very low cation exchange capacities and are highly leached, there are serious concerns about the effects of $\mathrm{N}$ and $\mathrm{P}$ fertilizers applied to landscapes on the quality of surface and groundwaters. Excess $\mathrm{P}$ has been blamed for inland and coastal algal blooms, eutrophication of lakes, and proliferation of invasive cattails in the Florida Everglades (Anderson et al., 2002; Conley et al.,
2009; Paerl, 2009). Nitrate-N is considered a human health hazard to children at concentrations greater than $10 \mathrm{ppm}$ in drinking water (U.S. Environmental Protection Agency, 1995) but has also been implicated in the degradation of the near shore marine environments. As a result, a Florida statute (Urban Turf Fertilizer Rule RE-1.003) prohibits application of $\mathrm{P}$ in excess of $1.6 \mathrm{~g} \mathrm{P} / \mathrm{m}^{2} /$ year to home lawns unless justified by a soil test documenting a $\mathrm{P}$ deficiency in the soil. The recommended palm fertilizer application rate of $73 \mathrm{~g} \cdot \mathrm{m}^{-2}$ of canopy area four times per year results in $23 \mathrm{~g}$ of $\mathrm{N}$ and $2.5 \mathrm{~g}$ of $\mathrm{P}$ being applied per square meter per year (Broschat, 2005a). These palm fertilization recommendations also state that turfgrass growing within $15 \mathrm{~m}$ of a palm should be fertilized only with the 8-2-12 palm fertilizer because palm roots can extend $15 \mathrm{~m}$ or more from the trunk. Thus, the recommended palm fertilizer rate would result in $\mathrm{P}$ applications in excess of those allowable for home lawns in Florida. Furthermore, ordinances in some Florida counties prohibit the application of any $\mathrm{N}$ or $\mathrm{P}$ fertilizers during the rainy months of June through September as a result of concerns about runoff into coastal waters.

Palm requirements for $\mathrm{P}$ are unknown. Phosphorus deficiency in palms is believed to be rare, but it is not unknown. It has been experimentally induced in several species of palms in sand culture (Broschat, 1984; Bull, 1958) and has been observed on extremely $\mathrm{P}$-deficient soils $(\mathrm{P}<0.25 \mathrm{ppm})$ in south Florida (Broschat and Elliott, 2009). Symptoms of $P$ deficiency are uniform yellow-green discoloration of the foliage that could easily be confused with $\mathrm{N}$ deficiency or other problems (Broschat, 1984; Elliott et al., 2004). The most characteristic symptom of $\mathrm{P}$ deficiency, however, is a complete cessation of growth, something that will only be apparent if the palm is observed over time. This suggests that palm $\mathrm{P}$ requirements are much lower than those of most other crops where soil $\mathrm{P}$ concentrations in sandy soils lower than $20 \mathrm{ppm}$ are considered deficient in this element (Anon, 2007). Because most soils in southeastern United States where palms are grown probably contain sufficient $\mathrm{P}$ for normal palm growth without supplemental $\mathrm{P}$ provided by fertilizers, it may be possible to eliminate all $\mathrm{P}$ from routine palm fertilization programs, thus eliminating one potential source of environmental pollution.

Similarly, N requirements for palms in landscapes are largely unknown. Nitrogen deficiency is uncommon among palms growing in landscapes in southeastern United States but is occasionally observed in areca palm (Dypsis lutescens), queen palm [Syagrus romanzoffiana (Cham.) Glassman], and Veitchia $\mathrm{H}$. Wendl. spp. (Broschat, 2009). Still, although N deficiency is rare, $\mathrm{N}$ is the element that most strongly affects growth rate and thus $\mathrm{N}$ fertilization is needed for field production of palms and establishment and early growth phases in the landscape (Broschat and Moore, 2010, 2012). Soils containing organic matter appear to release sufficient $\mathrm{N}$ for good palm growth and quality and thus these 
soils may not require supplemental $\mathrm{N}$ to the degree that sand or calcareous soils do. In st. augustinegrass (Stenotaphrum secondatum) lawns, Broschat et al. (2008) showed that during the rainy summer months in south Florida, unfertilized turf had quality equal to turf receiving $23 \mathrm{~g} \mathrm{~N} / \mathrm{m}^{2} /$ year, presumably as a result of release of $\mathrm{N}$ from decomposing thatch and clippings. Thus, it may be possible to eliminate all $\mathrm{N}$ from landscapes fertilized during those rainy summer months of June through September in areas where N applications are prohibited. Because $\mathrm{K}, \mathrm{Mg}$, and micronutrient requirements of palms are greatest during the summer months as a result of rapid growth, and these elements are not considered to be environmental pollutants, applications of an $8 \mathrm{~N}-0 \mathrm{P}-10 \mathrm{~K}-4 \mathrm{Mg}$ plus micronutrients (hereafter 8-0-12) palm fertilizer in February, May, and November but a no- $\mathrm{N}$ equivalent product such as $0 \mathrm{~N}-0 \mathrm{P}-$ $13.3 \mathrm{~K}-6 \mathrm{Mg}$ (hereafter $0-0-16$ ) in August should theoretically provide adequate nutrition for palms while reducing $\mathrm{N}$ inputs and eliminating all $\mathrm{P}$ inputs into the environment.

Finally, as discussed previously, application of a typical turfgrass fertilizer that is relatively high in $\mathrm{N}$, but low in $\mathrm{K}$, and contains no $\mathrm{Mg}$ or micronutrients, either directly to palms or indirectly through application to turf as far away as $9 \mathrm{~m}$ from a palm, has been shown to induce or exacerbate $\mathrm{K}$ and $\mathrm{Mg}$ deficiencies in several species of palms, sometimes fatally (Broschat, 2005a; Broschat et al., 2008; Broschat and Moore, 2010). As a result, Broschat (2005a) recommends fertilizing any turf within $15 \mathrm{~m}$ of a palm only with an 8-2-12 palm fertilizer to prevent such problems. However, in some landscape situations, landscape professionals may not be able to control what is being applied to adjacent turf in the landscape. If the 8-2-12 palm fertilizer is applied to the palm at its recommended rate and turf under or near the palm receives a typical turf fertilizer that is high in $\mathrm{N}$ but low in $\mathrm{K}$ and contains no $\mathrm{Mg}$ or micronutrients, the combined $\mathrm{N}$ from these applications could result in excessively high $\mathrm{N}: \mathrm{K}$ and $\mathrm{N}: \mathrm{Mg}$ ratios and exacerbate $\mathrm{K}$ and $\mathrm{Mg}$ deficiencies in the palms. Under such circumstances, application of a palm fertilizer that contains no $\mathrm{N}$ such as $0-0-16$ to the area under the palm canopy could potentially mitigate the negative effects of the nearby turf fertilization.

The objectives of this experiment were to determine if: 1) areca palms can be grown without supplemental P in sandy or calcareous landscape soils; 2) areca palms can grow without supplemental $\mathrm{N}$ during the summer rainy months of June through September in southern Florida; and 3) a $0-0-16$ fertilizer can be used to mitigate potential damage to palms caused by application of high $\mathrm{N}$ fertilizers to palms or nearby turfgrass.

\section{Materials and Methods}

Areca palms were used because they are sensitive to all of the common deficiencies associated with palms, including N. A field planting of areca palms was established in
Davie, FL, in May 2010 by planting 10-L container-grown palms on $4.5-\mathrm{m}$ centers in a plot of Margate fine sand soil (siliceous, hyperthermic Mollic Psammaquent) and another nearby plot having 30 to $40 \mathrm{~cm}$ of calcareous fill soil (crushed limestone) added to the surface, the latter being typical of soils used for planting palms in street medians, highway rights-of-way, and many new commercial and residential landscapes in Florida. Physical and nutrient analysis results of four replicate samples of each of these soils was determined by A \& L Southern Laboratories (Table 1).

The design was split plot with three blocks of three replicate palms each per treatment and soil type. The area between the palms was planted with st. augustinegrass sod to resemble a typical mixed landscape. The field was irrigated three times per week during the first 6 months of establishment and two times per week thereafter using overhead irrigation designed to deliver $\approx 2 \mathrm{~cm}$ of water per application.

To enhance establishment, all palms received $75 \mathrm{~g}$ of 8-2-12 fertilizer broadcasted to the area under the canopy at the time of transplant and again 3 months later. Experimental fertilizer treatments began 6 months after planting. Fertilizers were applied every 3 months (February, May, August, and November) by uniformly broadcasting the materials by hand over a $1-\mathrm{m}^{2}$ area surrounding each palm. The area under the canopy of the palms was maintained relatively vegetation-free using directed sprays of glyphosate herbicide. Within each soil type, palms were fertilized as shown in Table 2. The objective was to provide $5.9 \mathrm{~g}$ of $\mathrm{N} / \mathrm{m}^{2}$ every 3 months to all fertilized treatments and $7.3 \mathrm{~g}$ of $\mathrm{K} / \mathrm{m}^{2}$ for all treatments except 1,2 , and 7 . The $8-0-12,8-2-12$, and $0-0-16$ products had all of their $\mathrm{N}, \mathrm{K}$, and $\mathrm{Mg}$ in controlled-release form

(3-month release), whereas the $24 \mathrm{~N}-0 \mathrm{P}-$ $9.2 \mathrm{~K}$ (hereafter $24-0-11$ ) and $32 \mathrm{~N}-0 \mathrm{P}-$ $8.3 \mathrm{~K}$ (hereafter $32-0-10$ ) had $\approx 25 \%$ and $43 \%$, respectively, of their $N$, but none of their $\mathrm{K}$, in controlled-release form.

In Dec. 2013 all palms were measured for initial height to the tip of the tallest fully extended leaf (the best indicator of living palm size). The number of leaves on the three largest stems per plant were counted and used as a measure of the severity of $\mathrm{K}$ deficiency (Broschat and Gilman, 2013). Palms were also subjectively visually rated on a scale of 1 to $5(1=$ severely deficient, $3=$ moderate deficiency severity, and $5=$ no trace of deficiency symptoms) for severity of $\mathrm{N}$ and $\mathrm{K}$ deficiency and new leaf chlorosis (a symptom of $\mathrm{Fe}$ and/or Mn deficiency). Nitrogen deficiency symptoms in this species include light orange-green leaflets with the petiole, rachis, and crownshaft being bright golden orange (Broschat, 2005b; Broschat and Elliott, 2004). Potassium deficiency caused translucent orange spotting and leaflet tip necrosis on the oldest leaves (Broschat, 1990). Measurements and ratings were performed before the first cold weather of the winter to eliminate the possibility of confusing chilling injury symptoms with those of $\mathrm{K}$ deficiency. At this time leaf samples consisting of the middle leaflets of the youngest fully expanded leaves on each shoot were also collected for nutrient analysis. Samples were digested using a modified $\mathrm{H}_{2} \mathrm{SO}_{4}-\mathrm{H}_{2} \mathrm{O}_{2}$ method (Hach et al., 1987) and analyzed for $\mathrm{N}$ by an autoanalyzer (Seal Analytical, Mequon, WI), P by the ascorbic acid method (Kuo, 1996), and $\mathrm{K}, \mathrm{Mg}, \mathrm{Fe}$, and $\mathrm{Mn}$ by atomic absorption spectroscopy (Perkin-Elmer, Waltham, MA).

Because the various plant quality measurements used were all to some degree intercorrelated, principal component analysis

Table 1. Physical and chemical properties of the calcareous fill and native sand soils in Davie, FL. ${ }^{\mathrm{z}}$

\begin{tabular}{lccccccc}
\hline Soil type & $\begin{array}{c}\text { Organic } \\
\text { matter }(\%)\end{array}$ & $\begin{array}{c}\text { Bray 1-P } \\
(\mathrm{ppm})\end{array}$ & $\mathrm{K}(\mathrm{ppm})$ & $\mathrm{Mg}(\mathrm{ppm})$ & $\mathrm{Ca}(\mathrm{ppm})$ & $\mathrm{pH}$ & $\begin{array}{c}\text { CEC } \\
(\mathrm{meq} / 100 \mathrm{~g})\end{array}$ \\
\hline Fill & 2.5 & 1.8 & 3.8 & 9.8 & 1433 & 8.4 & 7.3 \\
Native sand & 3.3 & 2 & 2.8 & 20.5 & 825 & 6.5 & 4.7 \\
\hline
\end{tabular}

${ }^{\mathrm{z}}$ Data are means of four replicate samples from each soil type. Analyses were performed by A \& L Southern Agricultural Laboratory, Pompano Beach, FL.

$\mathrm{P}=$ phosphorus $\mathrm{K}=$ potassium $; \mathrm{Mg}=$ magnesium $; \mathrm{Ca}=$ calcium $; \mathrm{CEC}=$ cation exchange capacity.

Table 2. Fertilizer treatments applied to areca palms (Dypsis lutescens) planted in calcareous fill or native sand soils in Davie, FL.

\begin{tabular}{|c|c|c|c|c|c|c|c|c|}
\hline \multirow[b]{2}{*}{ Treatment } & \multirow[b]{2}{*}{ Formulation } & \multirow[b]{2}{*}{ Application times } & \multicolumn{6}{|c|}{ Amount applied (g/m²/year) } \\
\hline & & & $\mathrm{N}$ & $\mathrm{P}$ & $\mathrm{K}$ & $\mathrm{Mg}$ & $\mathrm{Fe}$ & $\mathrm{Mn}$ \\
\hline 1 & No fertilizer & & 0 & 0 & 0 & 0 & 0 & 0 \\
\hline 2 & $24-0-11^{z}$ & February, May, August, November & 23.5 & 0 & 9.0 & 0 & 2.9 & 1.0 \\
\hline \multirow[t]{2}{*}{3} & $24-0-11$ & February, May, August, November & 23.5 & 0 & 9.0 & 0 & 2.9 & 1.0 \\
\hline & $0-0-16^{\mathrm{y}}$ & February, May, August, November & 0 & 0 & 20.0 & 8.8 & 0.9 & 2.9 \\
\hline 4 & $8-0-12^{y}$ & February, May, August, November & 23.5 & 0 & 30.0 & 18.0 & 3.5 & 3.8 \\
\hline \multirow[t]{2}{*}{5} & $8-0-12$ & February, May, November & 17.6 & 0 & 22.5 & 13.5 & 2.6 & 2.8 \\
\hline & $0-0-16$ & August & 0 & 0 & 7.5 & 3.3 & 0.3 & 1.1 \\
\hline 6 & $8-2-12^{y}$ & February, May, August, November & 23.5 & 2.6 & 30.0 & 12.0 & 4.5 & 3.8 \\
\hline 7 & $32-0-10^{x}$ & February, May, August, November & 23.5 & 0 & 6.1 & 0 & 1.5 & 0 \\
\hline \multirow[t]{2}{*}{8} & $32-0-10$ & February, May, August, November & 23.5 & 0 & 6.1 & 0 & 1.5 & 0 \\
\hline & $0-0-16$ & February, May, August, November & 0 & 0 & 20.0 & 8.8 & 0.9 & 2.9 \\
\hline
\end{tabular}

${ }^{\mathrm{z} L e s c o,}$ Cleveland, $\mathrm{OH}$.

y Nurserymen's Sure Gro, Vero Beach, FL.

${ }^{\mathrm{x}}$ Scotts Co., Marysville, OH.

$\mathrm{N}=$ nitrogen; $\mathrm{P}=$ phosphorus $; \mathrm{K}=$ potassium; $\mathrm{Mg}=$ magnesium $; \mathrm{Fe}=$ iron; $\mathrm{Mn}=$ manganese . 
was used to reduce the five original quality variables to a single index of overall quality, namely the scores on the first principal component (Broschat, 1979). All data were standardized to a mean of 0 and a SD of 1 to eliminate the effects of measurement unit scale differences using PROC STANDARD (SAS Version 9.2; SAS Inst., Cary, NC). Principal component analysis was performed using PROC PRINCOMP with scoring by PROC SCORE. In this analysis the first principal component accounted for $\approx 58 \%$ of the variance of the original five variables (Table 3). All five of the original variables showed high positive correlations with the first principal component, making it a useful index of overall quality. Similarly, principal component analysis using only the plant size variables of height and number of leaves produced a useful index for plant size. In this case, the first principal component accounted for nearly $89 \%$ of the variability in the original two plant size variables. The plant size and overall plant quality scores as well as the leaf nutrient analysis data were subjected to analysis of variance (PROC GLM) with mean separations done by the Waller-Duncan k-ratio method $(P=0.05)$. Pearson correlation coefficients generated using PROC CORR were used to demonstrate relationships among the various plant quality and nutrient composition variables.

\section{Results and Discussion}

Control plants receiving no fertilizer had the lowest quality scores on both the native sand soil and the calcareous fill soil (Table 4). Analysis of variance on visual rating data

Table 3. Correlations of the original areca palm (Dypsis lutescens) quality variables with the first principal component for principal component analyses using all plant quality variables (Quality) or only plant size variables (Size).

\begin{tabular}{lcc}
\hline Variable & Quality & Size \\
\hline Height & 0.508 & 0.707 \\
Leaves & 0.506 & 0.707 \\
Nitrogen rating & 0.386 & \\
Potassium rating & 0.458 & \\
Chlorosis & 0.355 & \\
Eigenvalue & 2.940 & 1.772 \\
Proportion of variance & 0.588 & 0.886 \\
\hline
\end{tabular}

showed that unfertilized palms had significantly lower ratings for $\mathrm{N}, \mathrm{K}$, and chlorosis than for all fertilized treatments (data not shown).

Fertilization of areca palms with a $24-0-11$ or 32-0-11 turf fertilizer (Treatments 2 and 7) significantly reduced overall palm quality on the fill soil but not on the sand soil (Table 4). The use of these fertilizers alone also reduced palm size on the fill soil as did the $32-0-11$ fertilizer on the sand soil. However, addition of $0-0-16$ to $24-0-11$ or $32-0-11$-treated palms (Treatments 3 and 8) to maintain proper $\mathrm{N}: \mathrm{K}$ ratios for palms resulted in plant quality similar to that of palms receiving the standard 8-2-12 fertilizer (Treatment 6) on both soil types. Analysis of variance of the original variables data showed that $\mathrm{K}$ ratings, number of leaves (a measure of $\mathrm{K}$ deficiency severity), and overall height were significantly lower for palms receiving only the two turf fertilizers on the fill soil (data not shown). Because $\mathrm{N}$ ratings were not similarly affected, this reduction in plant quality can be attributed to insufficient $\mathrm{K}$ in the turf fertilizer treatments.

For both soils, areca palms fertilized with 8-0-12 year-round (Treatment 4 ) or $8-0-12$ in February, May, and November but 0-0-16 in August (Treatment 5) had equivalent quality as those receiving the standard 8-2-12 fertilizer (Treatment 6) (Table 4). This suggests that $\mathrm{P}$ was not a limiting factor in areca palm growth in either soil. Analysis of soil samples from both soil types showed $\mathrm{P}$ concentrations of less than $2 \mathrm{ppm}$ (Table 1), levels that are considered very low for most crops (Anon, 2007), but appear to be adequate for areca palms. At no time were symptoms of $\mathrm{P}$ deficiency observed on palms in any treatment.

The equivalent quality of areca palms grown with 8-0-12 applied year-round and those receiving 8-0-12 in February, May, and November but $0-0-16$ in August also suggests that $\mathrm{N}$ is not a limiting factor during the summer months. This may be the result of decomposition of organic matter in the soil releasing $\mathrm{N}$ or reserves of $\mathrm{N}$ within the plants that are sufficient to carry them over until $\mathrm{N}$ is reapplied in November. Nitrate in precipitation may also have been a contributing factor. Broschat et al. (2008) showed that during the rainy summer months in south Florida, unfertilized st. augustinegrass (Stenotaphrum secondatum) had quality equal to grass receiving $23 \mathrm{~g} \mathrm{~N} / \mathrm{m}^{2} /$ year.

On both soils areca palms receiving only 32-0-10 (Treatment 7) generally had the highest leaf $\mathrm{N}, \mathrm{P}, \mathrm{K}$, and $\mathrm{Fe}$ concentrations (Table 5). Unfertilized control palms growing in the sand soil similarly had high concentrations of $\mathrm{N}, \mathrm{P}$, and $\mathrm{Mg}$ in their leaves. These were treatments that produced palms with the lowest size scores and overall quality scores (Table 4). Addition of $0-0-16$ to palms receiving 32-0-10 resulted in lower leaf $\mathrm{N}, \mathrm{P}, \mathrm{Mg}, \mathrm{Mn}$, and $\mathrm{Fe}$ concentrations, but larger size and overall quality, similar to those in palms receiving one of the $8-0-12$ treatments.

The high positive correlations (Tables 3 and 6) between $\mathrm{N}$ and $\mathrm{K}$ deficiency ratings and chlorosis severity with palm size and overall quality suggest that $\mathrm{N}, \mathrm{K}$, and a micronutrient responsible for the new leaf chlorosis were limiting palm growth and quality. Correlation analysis of the data with both soil types combined showed significant negative correlations between plant size or overall plant quality and leaf concentrations of $\mathrm{N}$, $\mathrm{P}, \mathrm{K}, \mathrm{Mg}$, and $\mathrm{Fe}$ (Table 6). This suggests a strong dilution effect for these elements. However, leaf Mn concentrations were positively correlated with both plant size and overall plant quality, indicating that $\mathrm{Mn}$ was likely a deficient and limiting element in this experiment.

Leaf $\mathrm{K}$ concentrations were not well correlated with any plant quality or leaf nutrient concentration variable except for leaf $\mathrm{N}$ and $\mathrm{P}$ (Table 6). Because $\mathrm{K}$ is a mobile element within palms, new leaves such as those sampled for nutrient analysis usually show little of the variability in leaf $\mathrm{K}$ concentrations that older leaves show and are thus poor indicators of plant $\mathrm{K}$ status (Broschat, 1997; Broschat and Elliott, 2004). In general, leaf nutrient concentrations were poorly correlated with the severity of visual deficiency symptoms as a result of these dilution effects.

Chlorosis severity was also negatively correlated with leaf concentrations of all elements except for $\mathrm{Mn}$, suggesting that $\mathrm{Mn}$ deficiency had a stronger effect on palm

Table 4. Overall plant quality and size scores for areca palms (Dypsis lutescens) grown in native sand soil or a calcareous fill soil in southern Florida. ${ }^{\mathrm{z}}$

\begin{tabular}{|c|c|c|c|c|c|c|}
\hline \multirow[b]{2}{*}{ Treatment } & \multirow[b]{2}{*}{ Fertilizer } & \multirow[b]{2}{*}{ Application times } & \multicolumn{2}{|c|}{ Native sand soil } & \multicolumn{2}{|c|}{ Calcareous fill soil } \\
\hline & & & Quality score & Size score & Quality score & Size score \\
\hline 1 & No fertilizer & & $89.5 \mathrm{~b}^{\mathrm{y}}$ & $95.6 \mathrm{~b}$ & $58.3 \mathrm{~b}$ & $67.7 \mathrm{~b}$ \\
\hline 2 & $24-0-11$ & February, May, August, November & $101.2 \mathrm{ab}$ & $119.8 \mathrm{ab}$ & $68.1 \mathrm{~b}$ & $79.6 \mathrm{~b}$ \\
\hline 3 & $\begin{array}{l}24-0-11 \\
\text { Plus } 0-0-16\end{array}$ & $\begin{array}{l}\text { February, May, August, November } \\
\text { February, May, August, November }\end{array}$ & $105.0 \mathrm{ab}$ & $124.6 \mathrm{ab}$ & $91.4 \mathrm{a}$ & $107.5 \mathrm{a}$ \\
\hline 4 & $8-0-12$ & February, May, August, November & $114.6 \mathrm{a}$ & $136.6 \mathrm{a}$ & $92.6 \mathrm{a}$ & $109.1 \mathrm{a}$ \\
\hline 5 & $\begin{array}{l}8-0-12 \\
0-0-16\end{array}$ & $\begin{array}{l}\text { February, May, November } \\
\text { August }\end{array}$ & $115.9 \mathrm{a}$ & $136.6 \mathrm{a}$ & $91.1 \mathrm{a}$ & $111.2 \mathrm{a}$ \\
\hline 6 & $8-2-12$ & February, May, August, November & $100.2 \mathrm{ab}$ & $138.1 \mathrm{a}$ & $89.3 \mathrm{a}$ & $107.5 \mathrm{a}$ \\
\hline 7 & $32-0-10$ & February, May, August, November & $100.3 \mathrm{ab}$ & $99.0 \mathrm{~b}$ & $68.4 \mathrm{~b}$ & $80.1 \mathrm{~b}$ \\
\hline 8 & $\begin{array}{l}32-0-10 \\
\text { Plus } 0-0-16\end{array}$ & $\begin{array}{l}\text { February, May, August, November } \\
\text { February, May, August, November }\end{array}$ & $100.2 \mathrm{ab}$ & $118.6 \mathrm{ab}$ & $89.3 \mathrm{a}$ & $103.1 \mathrm{a}$ \\
\hline$P$ value & & & 0.033 & 0.011 & $<0.0001$ & $<0.0001$ \\
\hline
\end{tabular}

${ }^{\mathrm{z}}$ Data are means for nine replicate palms for each treatment and soil type.

${ }^{\mathrm{y}}$ Mean separation within columns by the Waller-Duncan k-ratio method, $P=0.05$. 
Table 5. Nutrient concentrations for areca palms (Dypsis lutescens) grown in calcareous fill or native sand soils in southern Florida. ${ }^{2}$

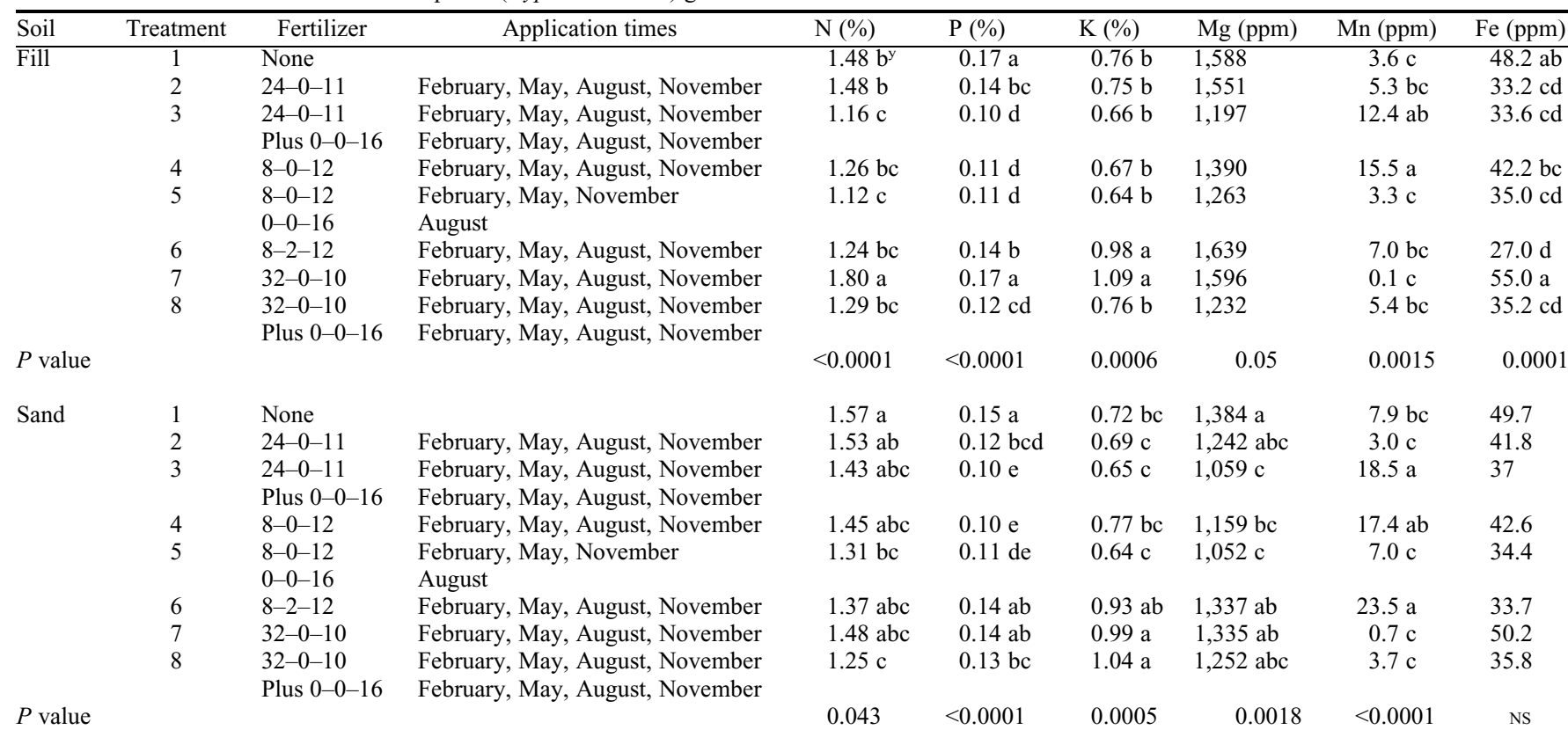

${ }^{2}$ Data represent means from nine replicate plants per treatment.

${ }^{\mathrm{y}}$ Mean separation by the Waller-Duncan k-ratio method, $P=0.05$.

$\mathrm{N}=$ nitrogen; $\mathrm{P}=$ phosphorus; $\mathrm{K}=$ potassium; $\mathrm{Mg}$ = magnesium; $\mathrm{Mn}=$ manganese $; \mathrm{Fe}=$ iron; $\mathrm{NS}=$ nonsignificant.

Table 6. Pearson correlations among quality, size, nitrogen and potassium deficiency ratings, new leaf chlorosis severity, and leaf nutrient concentration variables in areca palms (Dypsis lutescens). ${ }^{\mathrm{T}}$

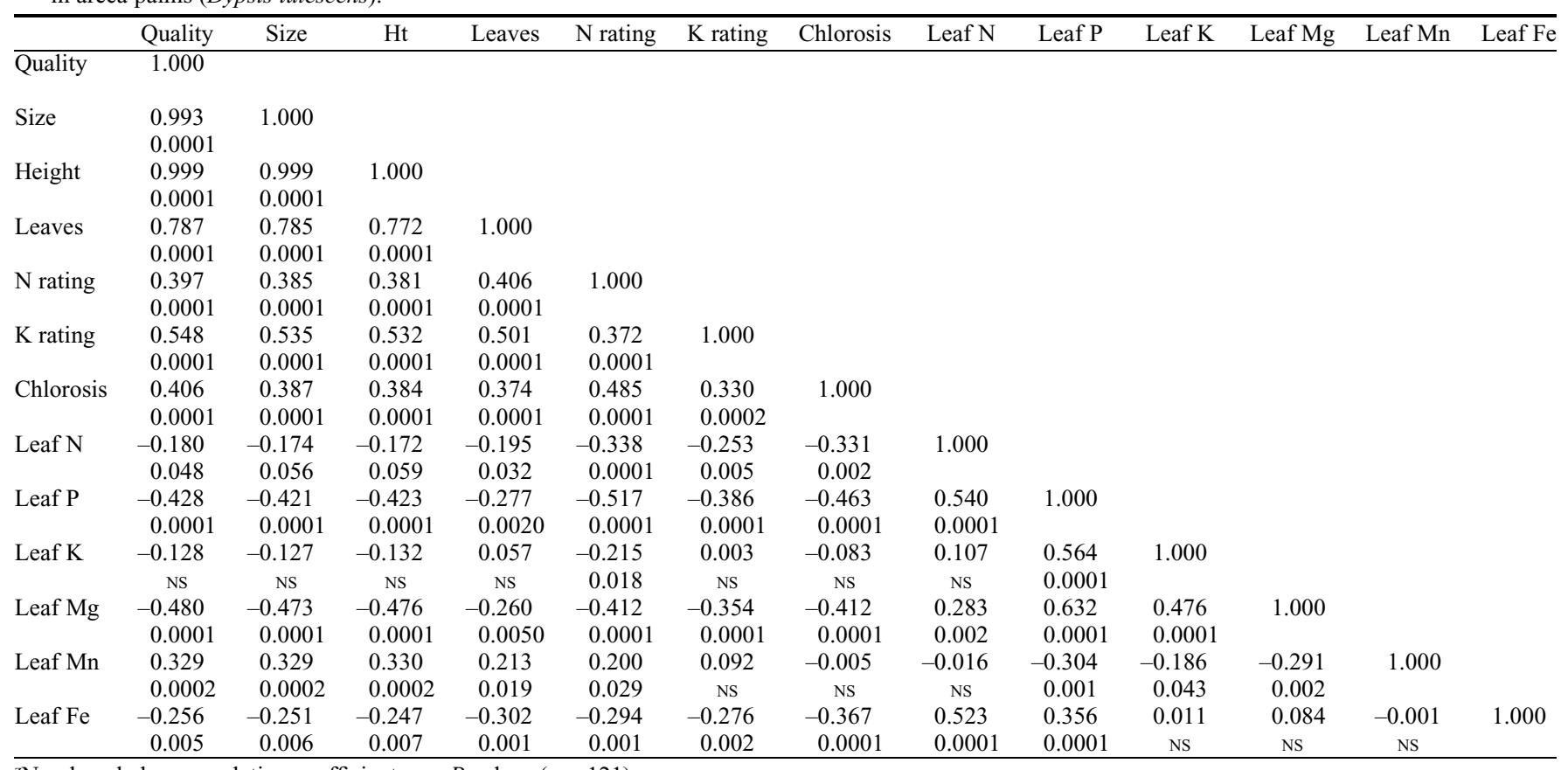

${ }^{\mathrm{z}}$ Numbers below correlation coefficients are $P$ values $(\mathrm{n}=121)$.

$\mathrm{N}=$ nitrogen; $\mathrm{P}=$ phosphorus; $\mathrm{K}=$ potassium; $\mathrm{Mg}$ = magnesium; $\mathrm{Mn}=$ manganese; $\mathrm{Fe}=$ iron; $\mathrm{NS}=$ nonsignificant.

growth than on chlorosis severity. Thus, more chlorotic palms did not have lower Mn concentrations in their leaves because reduced growth rates reduced the chances for Mn dilution within these plants. All of the palms in both soil types had extremely low leaf Mn concentrations with some below the detection limits for this element by our analytical methods (Table 5). In contrast, Mills and Jones (1996) consider 47 ppm to be the lower sufficiency limit for this species. With the exception of $\mathrm{Mg}$, all of the other elements examined in this study were within the sufficiency range given for areca palms.

In most palm species, Mn deficiency is distinguished from $\mathrm{Fe}$ deficiency by the presence of longitudinal necrotic streaking (Broschat, 2005b; Elliott et al., 2004). Although some areca palms in this study did indeed show this streaking, most simply showed uniform chlorosis on the youngest leaves. For this reason the chlorosis could not readily be attributed to one or the other of these two elements by visual symptoms alone. The very low leaf Mn concentrations, the positive correlations between leaf $\mathrm{Mn}$ concentrations and plant size and overall quality, and the negative correlations between leaf $\mathrm{Fe}$ concentrations and those quality variables are strong indicators that the observed chlorosis was caused by $\mathrm{Mn}$ deficiency. The high $\mathrm{pH}$ of the fill soil in 
particular likely contributed to reduced $\mathrm{Mn}$ availability in this study (Kabata-Pendias and Pendias, 1984; Lindsay, 1991).

In summary, areca palms growing on a sandy native soil or on a calcareous fill soil grew equally well with $8-0-12$ fertilizer and the traditional 8-2-12 formulation, indicating that $\mathrm{P}$ could be eliminated from the fertilizer without affecting palm growth or quality. Fertilization with high $\mathrm{N}: \mathrm{K}$ ratio fertilizers typically used on st. augustinegrass reduced palm growth and overall quality, but these negative effects could be mitigated by supplementing these products with a controlled-release palm fertilizer having an analysis of $0-0-16-6 \mathrm{Mg}$ plus micronutrients. Substitution with $0-0-16$ for $8-0-12$ for the summer rainy season application resulted in similar palm quality to that obtained when $8-0-12$ or $8-2-12$ was applied year-round. Nitrogen, K, and Mn were the primary limiting elements in this study, but leaf nutrient concentrations were found to be poor indicators of plant quality and nutritional status as a result of strong dilution effects. Because areca palms are susceptible to the same nutrient deficiencies as other common landscape palms, the results from this study should be applicable to other species growing under similar environmental conditions.

\section{Literature Cited}

Anderson, D.M., P.M. Gilbert, and J.M. Burkholder. 2002. Harmful algal blooms and eutrophication: Nutrient sources, composition, and consequences. Estuaries 25:704-726.

Anon, 2007. Procedures used by state soil testing laboratories in the southern region of the United States. Southern Cooperative Series Bull. No. 190-D.
Broschat, T.K. 1979. Principal component analysis in horticultural research. HortScience 14:114-117.

Broschat, T.K. 1984. Nutrient deficiency symptoms in five species of palms grown as foliage plants. Principes 28:6-14.

Broschat, T.K. 1990. Potassium deficiency of palms in south Florida. Principes 34:151-155.

Broschat, T.K. 1997. Nutrient distribution, dynamics, and sampling in coconut and Canary Island date palms. J. Amer. Soc. Hort. Sci. 122:884-890.

Broschat, T.K. 1999. Nutrition and fertilization of palms. Palms 43:73-76.

Broschat, T.K. 2005a. Fertilization of field-grown and landscape palms in Florida. Univ. Fla. Env. Hort. Dept. Circ. ENH1009. 19 Feb. 2015. $<$ http://edis.ifas.ufl.edu/ep261>.

Broschat, T.K. 2005b. Nutrient deficiencies of landscape and field-grown palms in Florida. Univ. Fla. Env. Hort. Dept. Circ. ENH1018. 19 Feb. 2015. <http://edis.ifas.ufl.edu/ep273>.

Broschat, T.K. 2009. Palm nutrition and fertilization. HortTechnology 19:690-694.

Broschat, T.K. and M.L. Elliott. 2004. Nutrient distribution and sampling for leaf analysis in st. augustinegrass. Commun. Soil Sci. Plant Anal. 35:2357-2367.

Broschat, T.K. and M.L. Elliott. 2005. A key to common landscape palm disorders and diseases in the continental United States. Palms 49:143148.

Broschat, T.K. and M.L. Elliott. 2009. Effects of fertilization and microbial inoculants applied at transplanting on the growth of Mexican fan palm and queen palm. HortTechnology 19:324-330.

Broschat, T.K. and E.F. Gilman. 2013. Effects of fertilization and pruning on canopy leaf number and potassium deficiency symptom severity in Sabal palmetto. Palms 57:84-88.

Broschat, T.K. and K.A. Moore. 2010. Effects of fertilization on the growth and quality of container-grown areca palms and Chinese hibiscus during establishment in the landscape. HortTechnology 20:389-394.

Broschat, T.K. and K.A. Moore. 2012. Fertilization rate and placement effects on areca palms transplanted from containers or a field nursery. Arboriculture and Urban Forestry 38:146-150.

Broschat, T.K., D.R. Sandrock, M.L. Elliott, and E.F. Gilman. 2008. Effects of fertilizer type on quality and nutrient content of established landscape plants in Florida. HortTechnology 18:278-285.

Bull, R.A. 1958. Symptoms of calcium and phosphorus deficiency in oil palm. Nature 182:1749-1750.

Conley, D.J., H.W. Paerl, R.W. Howarth, D.F. Boesch, S.P. Seitzinger, K.E. Havens, C. Lancelot, and G.E. Likens. 2009. Controlling eutrophication: Nitrogen and phosphorus. Science 323 1014-1015.

Elliott, M.L., T.K. Broschat, J.Y. Uchida, and G.W Simone. 2004. Compendium of ornamental palm diseases and disorders. Amer. Phytopath. Soc. Press, St. Paul, MN.

Hach, C.C., B.K. Bowden, A.B. Koplove, and S.V. Brayton. 1987. More powerful peroxide Kjeldahl digestion method. J. Offic. Anal. Chem. 70:783-787.

Kabata-Pendias, A. and H. Pendias. 1984. Trace elements in soils and plants. CRC Press, Boca Raton, FL.

Kuo, S. 1996. Phosphorus, p. 869-920. In: Bartels, J.M. (ed.). Methods of soil analysis. Part 3. Chemical methods. Soil Sci. Soc. Amer., Madison, WI

Lindsay, W.L. 1991. Inorganic equilibria affecting micronutrients in soils, p. 89-112. In: Mortvedt, J.J., F.R. Cox, L.M. Shuman, and R.M. Welch (eds.). Micronutrients in agriculture. 2 nd ed. Soil Sci. Soc. Amer., Madison, WI.

Mills, H.A. and J.B. Jones, Jr. 1996. Plant analysis handbook II. Micro-Macro Publishing, Athens, GA.

Paerl, H.W. 2009. Controlling eutrophication along the freshwater-marine continuum: Dual nutrient $(\mathrm{N}$ and $\mathrm{P})$ reductions are necessary. Estuaries Coasts 32:593-601.

U.S. Environmental Protection Agency. 1995. National water quality: 1994 report to Congress (appendices). U.S. Environmental Protection Agency, Washington, DC. 